\title{
The Implementation of Scientific Approach for Teaching English in Senior High School: Voices from the Field
}

\author{
Afrianto \\ Faculty of Teachers Training and Education, Universitas Riau \\ Pekanbaru, Indonesia \\ afrianto.a@lecturer.unri.ac.id
}

\begin{abstract}
This paper is aimed at reporting the results of a qualitative study investigating how English teachers implement the Scientific Approach (SA) for teaching English in a Senior High School in Pekanbaru. This study is particularly intended to answer three research questions: 1) What is teachers' understanding on the Scientific Approach; 2) How do they implement the mandated approach in their classroom; and 3) What kinds of problems they encountered during the implementation of the approach. Three English teachers wererandomly selected as the participants of this research. Data were collected through semi-structured interviews with each participant. The findings showed that the English teachers were rather skeptical with the SA. They did not really follow all stages of teaching mandated in the SA during the implementation. All the participants reported that most of the time they made some adjustments during their teaching procedures. Two participants reported that the main problems they faced during the implementation of SA were about challenges to make the students active and the complicated procedures of assessment. Lack of supervision on the new curriculum implementation has also been reported as another major problem. The findings imply that the implementation of this new curriculum may have been not working well in the field yet. It requires an integrated and well-planned effort from related parties to make sure that the suggested approach can positively affect the effectiveness of English teaching in the field.
\end{abstract}

Keywords-curriculum implementation, scientific approach, English teaching, senior high school, Indonesia.

\section{INTRODUCTION}

As the foundation of teaching and learning process, curriculum normally covers subject matters and a set of students' learning experiences. The curriculum is "all the learning experiences planned and directed by the school to attain its educational goals" [1]. Although it is not the only factor, a curriculum plays a significant role for the success of students' learning. It guides teachers about what to teach and how to teach in their classrooms. The term 'curricula' itself denotes a movement from a starting point to a destination, a movement that proceeds along some path. It functions like a compass for teachers to navigate their teaching journey in helping the students learn and achieve their dreams. Curriculum is the entire range of experiences, both directed and undirected, concerned in unfolding the abilities of the individual; or it is the series of consciously directed training experiences that the schools use for completing and perfecting the unfoldment [2].

With some pros and cons, many high schools in Indonesia have been implementing the latest curriculum which is well known by 2013 Curriculum (C-13) since mid2013. This $\mathrm{C}-13$ isbasically a continuation and a revision of the previous curricula, School-Based Curriculum (KTSP) and Competency-Based Curriculum (CBC). Although there are a lot of similarities between this $\mathrm{C}-13$ compared to the previous ones, such as in the emphasis on students centred learning and characters building of the students, this new curriculum also offers some relatively new ideas, such as introducing the use of Scientific Approach (SA) as the official recommended approach for teaching and learning in all subjects, including English subject.

TheSAin the context of teaching English adopts some principles and practices which are usually familiar in science class, like questioning, observing, associating, experimenting and networking. Therefore, it is important for English teachers to have a clear understanding about how it should be implemented. Because the SA is a relatively new approach in the context of teaching English in Indonesia, it is possible that they have some obstacles to the implementation of this approach in the classroom. Many of these challenges are likely to reduce the effectiveness of the teaching of English in schools, especially in Senior High School. For this reason, in this study, the researcher focused on documenting the English teachers' voices on the implementation of this SA in their classrooms. This study is specifically aimed at answering three research questions: 1) What is teachers' understanding on the Scientific Approach?; 2) How do they implement the mandated approach in their classroom?; and 3) What kinds of problems do they encounter during the implementation of the approach?

Curriculum experts provide various definitions about the curriculum. However, in general, their definitions refer to the view that the curriculum is a set of plans and arrangements regarding the objectives, content and learning materials as well as the means used to guide the implementation of learning activities to achieve specific 
educational objectives [3]. The success of an educational process, among others, is much influenced by the kind of the curriculum used. In addition to the content of what to teach, a curriculum usually also serves as guidance related to what methods should be used by teachers in achieving the curriculum content.

Regarding the $\mathrm{C}-13$, which is currently being used in many schools in Indonesia, one of the important objectives of this curriculum is about the hope for the birth of the next Indonesian generations who are productive, creative, innovative, and with strong characters. The C-13 considers that if Indonesia's young generationsare able to innovate productively and creatively, they will be able to answer the future challenges which are believed to be more complicated and complex.

The hope to generate productive, creative, and innovative human resources is certainly not an easy job to make it true. It requires a strong cooperation and commitment from various stakeholders, such as the commitment of the principal, the creativity of teachers, learners' activity, socialization from the government, the availability of facilities and learning resources, conducive academic environment, and the participation of the school community [3]. Again, one of the keys to success is how teachers can translate the principles written in the curriculum document into practice teaching in the classroom. The successful implementation of the scientific approach is certainly also very dependent on the skills and understanding of teachers in the field.

The C-13 mandates the essence of the scientific approach to learning. The scientific approach is believed to be a golden bridge to the development of attitudes, skills, and knowledge of students. In the scientific approach, the scientists put forward the inductive reasoning rather than deductive reasoning. The deductive reasoning sees a common phenomenon to draw specific conclusions. In contrast, inductive reasoning looks at the phenomenon from specific situation to draw overall conclusions. Indeed, inductive reasoning puts specific evidence in relation to a broader idea.

The scientific method generally puts a unique phenomenon with a specific and detailed study to formulate general conclusions. The scientific method refers to the techniques of investigation of one or several phenomena or symptoms, acquire new knowledge, or correcting and integrating previous knowledge. To be called scientific, the search method (method of inquiry) should be based on evidence of the object which is observable, empirical and measurable with the principles of the specific reasoning. Therefore, the scientific method generally contains a series of activities of collecting data through observation or experimentation, process information or data, analyze and formulate, and test the hypothesis.

The learning process in the $\mathrm{C}-13$ is run through using this scientific approach. The learning process should touch the three domains, namely the attitude, knowledge, and skills. In the SA-based learning process, the attitudes domain is developed to focus on the substance or the transformation of teaching materials, so that learners know about the "why". The skills domain focus on the substance or the transformation of teaching materials so that learners know about the "how". The skills domain focuses on the substance or the transformation teaching materials so that learners know about the "what". The end result is an increase and balance between the ability to be a good man (soft skills) and people who have the skills and knowledge to live (hard skills) of learners that include aspects of competence, attitudes, skills and knowledge. With this kind of learning process, it is expected that the learning outcomes could lead the students to be a productive, creative, innovative, and effective human being through the strengthening of their attitudes, skills, and knowledge integratively.

An SA-based learning is believed to have more effective results than traditional learning. A study by Azizah for instance, revealed that in a traditional learning, retention of information from teachers is only by 10 percent after 15 minutes and the acquisition of contextual understanding is by 25 percent [4]. In a scientific approach based learning, retention of information from the teachers is more than 90 percent after two days and the acquisition of contextual understanding is around 50-70 percent. Some other studies on the implementation of the SA in the C-13have found out that the scientific approach will be able to meet the needs of learners in modern pedagogical dimensions of learning.

To be more specific, the training manual book of the C-13 published by Kemendikbud (2013) explains that there are seven criteria of a learning approach that can be regarded as a scientific learning. They are (1) Learning materials are based on facts or phenomena that can be explained by a certain logic or reasoning; not limited to approx, fantasy, legend, or a mere fairy tale; (2). Teachers' explanation, students' responses, and teachers-students educational interaction should be free of prejudice, subjective thinking or reasoning which deviated from the flow of logical thinking; (3). Teachers should encourage and inspire students to think critically, analytically and precisely identify, understand, solve problems, and apply the lessons; (4) The learning process should encourage and inspire students to think hypothetically in seeing the differences, similarities, and link to one another of the learning materials; (5). The learning process should encourage and inspire students to be able to understand, implement, and develop ways of rational and objective thinking in response to learning materials; (6). The learning process should be based on the concept, theory and empirical facts that can be accounted for; and (7). The learning objectives are formulated in a simple and clear, yet attractive presentation system.

As described by Kemendikbud (2013), the SA consists of five steps of teaching procedures. The first step is observing. In observing students are trained about seriousness, thoroughness and searching for information. The second is about questioning where students are 
expected able to develop creativity, curiosity and the ability to formulate questions. The third one is associating. Here, competencies that are developed are about being honest, particular, disciplined, and hard working. Next one is experimenting. Here, the students have to communicate with other and practice to appreciate the opinion from other friends. The last is networking, where students have to develop their ability to express the idea and practice their ability to use language [5].

\section{METHOD}

This qualitative study involved three experienced English teachers at a high school in Pekanbaru, Riau province. They were randomly chosen as participants of this study. This small number of participants is considered sufficient for a small scale qualitative project as a qualitative study typically does not intend to deal with issues of representativeness; rather what is more important is in the richness of the data. In addition, the findings are not intended for generalisation [6]. All data mentioned in this study are only valid for this specific context of the study. However, the findings might be also relevant for other contexts with similar situations.

For confidentiality reasons, all participants, as well as the name of the school, are referred by pseudonyms along this paper. Data were gathered through semi-structured interviews with each participant. Although there was a flexibility in conducting an interview, in this study, the interviews focused on exploring the answer to the three research questions. The interviews were recorded and then transcribed verbatim. The transcripts from the interviews were analysed using Flick (2002) three stages of data analysis: open coding (finding out all themes and categorising), axial coding (looking for the relationship among themes), and selective coding (selecting the relevant theme to be further explored and discussed). By using the data management tool, NVivo 10, data were coded and categorised based on themes and patterns [7]. These patterns then were analysed to produce themes, with reference to research questions and literature on curriculum implementation. These phases of analysis generated the findings discussed here.

\section{FINDING AND DISCUSSION}

As mentioned in the introductory section, there are three points that the researcher intended to explore through the semi-structured interviews; they are about teachers' understanding of the nature of the Scientific Approach, their implementation of the SA in their classroom teaching, and challenges they face during the implementation. Teachers' understanding in the context of this study includes their own definition as well as their perception of the Scientific Approach in the C-13.

Teachers' Understanding on the Scientific Approach: “... nothing new".
One of the questions asked during the interview was 'How do you define the Scientific Approach in the context of teaching English in a high school in Indonesia?" This question was intentionally asked to explore the teachers' basic understanding and or perception on the approach. It is believed that the teachers' clear understanding and their positive perception on the mandated approach will significantly determine the success and the effectiveness of their classroom teaching. Their understanding will guide them in implementing the approach.

Teachers' answers to this first question varied. It ranged from complex definitions involving stages mentioned in the curriculum to simple and unclear conceptualisation which did not really address the tenets of the SA. Falinda, one of the participants, for instance, clearly defined SA as 'an approach used in the C-13by which teachers need to do some stages, like observing, questioning, associating, networking and experimenting'. She even further emphasized the learner centered teaching as an essential spirit within this new curriculum.

It is more student-centered. Ya! I mean the students are demanded to be more active. For example, like by asking some questions. Eee because in former curriculum eee the teachers are the ones who always ask the questions to the students. And eee and after that, the students are also trained to find the information and collecting the information, they get the information and then they eee have the chance to conclude or to find out about the lesson, about the rules in... in the lesson.

(Falinda)

Yet, the other two teachers in this study seemed to define the SA as a teaching method which is more or less the same as the previous teaching methods they have used in the preceding curricula, like three stages of teaching - pre, whilst, and post teaching strategies. In their opinion, there are nothing new in this SA. They were even skeptical with this new SA saying that what is changed only the name, the year, not the content of the curriculum.

It is all the same, I think. ... I think in the last curriculum, when we teach reading to the students, we start from pre-reading activities, whilst, and post. Then, today they change the name. But, the content keeps the same, I think.

(Yenita)

I think for English, nothing new, I guess. Because I have got a training before in 1989 about PKG [Pelatihan Ketrampilan Guru] I got a chance to participate many times. So, I think the way we teach just the same. Of course, what is mentioned in the SA, like 'menanya' [questioning], and so on, of course in teaching English, we use it. We ask about their prior language before we come to teach new topic. ... Only changing the name. And I am 
wondering why should be made in such a kind of pattern, like menanya, mengobservasi, and bla bla. I don't like the 5M. I don't like.

(Bunga)

It can be clearly seen that both Yenita and Bunga are skeptical with this new curriculum. They do not seem to believe that this curriculum can be used as a guidance to have a better learning for their classes. This is likely due to the fact these two participants are two senior teachers in this school. They have been teaching English for almost thirty years. They have experienced teaching with several curricula, starting from CBSA Curriculum (1984), Competency-Based Curriculum (2004), School-Based Curriculum (2006) to the latest one - the 2013 curriculum. They may be true that basically they did not see any new ideas in the teaching procedures. It may also because they do not want to go out of their comfort zone in terms of teaching strategies. They became skeptical with changes and new ideas. This negative perception about the SA is even also enunciated by Falinda, the younger participant who actually could elaborate the concept of SA relatively well.

... but, but I think ya, in K-13 eee for English eee what the government says about the scientific method I dont think it really works for teaching language. (Falinda)

In a broader sense, these two opposite and intrigued understanding and perception of SA indicate that it is likely that many teachers have a different perception of the nature of SA. In other words, the finding is not only case-specific of this particular school. The different understanding and perception might be because not all teachers had enough training about this new curriculum [8]. In the case of this study, all participants mentioned that they only had once training about the C-13 implementation. Even, the teacher who could answer the definition quite elaboratively (Falinda) stated that she herself only had a half day socialization from the Ministry of National Education about this new curriculum. She understands about the SA is not from her training. It is possible only after she learns by herself from various sources, like from the internet, asking some senior teachers, or from books.

The gap in understanding about the SA may also happen for other English teachers in Indonesia. Some studies report that many teachers seem to have a lack of understanding about this SA [9]. Their main concerns are related to how to implement the five stages successfully in the classroom. These findings resemble with the Chinese teachers when implementing the new curriculum [10]. Their studies reveal that teachers do not understand well of the connotation, denotation, and relevant theories of curriculum and network resources in the class.

\footnotetext{
Classroom Implementation: "If am observed by a supervisor ..."
}

This section deals with the question about how the English teachers implement the SA in the classroom. Interviews with the three teachers revealed that in using the Curriculum 2013, the English teachers did not always use the five steps suggested in the scientific approach. No one reported that they followed all the five stages suggested in the $\mathrm{C}-13$ because of some reasons that have been previously discussed. Two teachers even reported that they did not really care if their classes have used the stages. What is more important for them is not about the name of the approach. It is more about whether they can facilitate the learning process in the class, regardless the name of the approach.

Rather than following the stages suggested by the government in implementing the new curriculum, the two teachers, Yenita and Bunga, mentioned that they almost never practiced the $5 \mathrm{M}$ strategies in their classroom. As previously indicated that they seemed to keep using their old teaching strategies, in this case it is three phases teaching techniques.

In pre-activity, like asking 'have you watched it? Have you ever gone somewhere? What do you think if I mention this word? What comes to your mind. Something like that. To activate their background knowledge. When we teach reading, in pre-reading we guide the students to the background knowledge of the students to come to the topic, and then in whilst reading, we come to the to the topic, so that the students have to understand: what is the main idea, what is text about, what is the purpose of the text, and at the end what is the conclusion from the students.

(Yenita)

The younger teacher, Falinda, however, reported that she had deliberately used the SA in her class. Yet, she could not completely follow all the stages. Most of the time she only did two or three stages. She got difficulty in implementing other two stages:

I don't really follow the steps. Because what I want in this case, my aim is that to invite the students to participate or to speak up. Mmm for example like eee I show them the picture. I show them the video, yea eee but before showing them the video or the picture, I asked them some questions first related to the topic.

(Falinda)

An interesting story is found from Bunga, a participant who is also a supervisor for the curriculum implementation in her school. Although she mentioned that most of the time she kept using her own way of teaching and did not apply the five stages suggested in the SA, in her written lesson plans, syllabus and in any other official teaching documents she actually wrote the SA. She did it for the sake of administration purposes only, not for her classroom teaching. She herself sometimes did the five 
stages, but only when she was observed by another supervisor coming to her classroom to see the implementation of the new curriculum.

Theoretically we make $5 \mathrm{M}$ in all our written documents. If am observed by a supervisor, I will practice the $5 \mathrm{M}$. Otherwise, I will come back to my own way of teaching. Because I don't think English teaching must be like that.

(Bunga)

This finding resembles findings from other researchers about the same topic. A qualitative study by Arifianti (2014) investigating the implementation of the scientific approach in teaching English at SMP SMPN 5 Malang, for instance, found that all English teachers did not do all the 5 stages in their English lesson. Other studies by Azizah (2015) and Kartikawati et al. (2015) reveal that most of English teachers at junior high schools get difficulties in facilitating the students to ask and answer the questions to their friends or teacher $[4,11]$. A recent study about the implementation of Scientific Approach for high school students in two high schools in Padang by Zaim (2017) also reports that among the five steps of the scientific approach, the teachers were not able to implement the observing and questioning steps optimally yet [9]. Meanwhile, in experimenting and associating the teachers have applied quite well, and in communicating the teachers have applied them optimally.

\section{Problems: "feeling dictated, ... complicated assessment"}

Extracted data from the semi-structured interviews reveal that there are two main problems raised by the three participants: a feeling of being dictated by the curriculum and complicated assessment procedures suggested in the curriculum. Falinda, for instance, mentioned that she felt to have a lack of freedom as an English teacher in her classroom due to detailed stages of teaching mandated by the 2013 Curriculum. Because of that reason, she was wondering how she could follow her own way of teaching. She particularly questioned the presentation part from the teacher during the lesson. Falinda claimed that many teachers in Indonesia also question the same issue.

... by following the steps given by the government, I feel a little bit ... what you call that? Eee, limited? $\mathrm{Ah}$ ! I was, I am handled by the steps. I am dictated by the steps. And ... and ... I have to follow the steps eee sequentially. And that's what I dont like $\ldots$

... you know eee the teacher feel feel confused about when the teachers have to present the lesson, I mean the presentation part. Yea, following the steps eee I couldn't find eee the place for the teacher of doing the presentation. And these questions are also asked by the other teachers around Indonesia; the presentation part.
(Falinda)

This feeling of being dictated by the curriculum indicates that teachers can be unhappy because of a very detailed manual of the curriculum implementation. It can undermine teachers' unique way of teaching. Another participant also complained about this saying that 'teaching is an art'. It is an individual and personalised journey in helping students learn something. Therefore, a strict curriculum can erode this uniqueness and block teachers' creativity in the classroom. In fact, when a teacher feels unhappy with hir or her own teaching strategy, it will negatively affect the effectiveness of his or her teaching performance.

Another issue raised by all participants was related to the complicated assessment rubrics suggested in C-13. It is indeed more complex than the form of assessment in the previous curricula. The latest curriculum requires teachers to assess students' learning progress with authentic based assessment covering all the three domains of Bloom Taxonomy (cognitive, affective, and psychomotor domains). Not only are the teachers expected to comprehensively assess these aspects, they also need to routinely fill in a lot of forms and rubrics. These forms and rubrics need to be submitted to school principal at a certain time. This administrative job has made the teachers busy. They seemed to be not happy with the complicated assessment system.

They feel it as a burden.

... teaching with those steps is fine with me. I can I can adjust myself. I can follow the steps. Ya! It's not not the problem. It depends on the creativity of the teachers. But giving the score or kind of evaluation or assessment eee .... is very complicated.

(Falinda)

Issues of this complicated assessment procedures have also been raised by many teachers across Indonesia, particular after the pilot project of new curriculum implementation finished. The complaints are not only because of the demanding nature of the assessment process, it is also because many of them do not really understand how to conduct the assessment using the new formats [12]. This is one of the reasons why this C-13 implementation was temporarily stopped by the Ministry of Education in 2015 [8]. The ministry thought that many school teachers were not ready yet to implement this new curriculum, including how to conduct the assessment.

In addition to these two major problems, participants of this study also mentioned the fact that they had a lack of training and supervision from related authorities about how to implement the curriculum. All of the teachers in this study reported that they had only once three days training about this $\mathrm{C}-13$. The training was conducted by the Ministry of Education in their city. Yet, they were not really satisfied with the quality of training due 
to the fact that the trainers were also their colleague - some English teachers who had got another training before. They did not get much from the training. This condition has been exacerbated by the fact that the quality control system did not work well during the curriculum implementation. Falinda reported that the curriculum supervisor only came once in a while and provided minimum feedback.

We have a supervisor, supervisor from Dinas Pendidikan. Eee they come to our class to see how we implement the curriculum. but most of the time they don't come. Maybe only once in a year

(Falinda)

In regard to these problems, participants of this study suggested that they government has to support them with more training about the $\mathrm{C}-13$. They also mentioned that the government needs to simplify the assessment part so it is workable and usable by the teachers. Then, they argued that it is important to give more freedom to the teachers to handle their classroom. They believe that teaching is an art and unique. Uniformity is considered to potentially block the uniqueness of each teachers' teaching styles.

\section{FINDING AND DISCUSSION}

Having implemented for more than four years, the 2013 curriculum implementation has not shown significance result to improve the quality of English teaching in Indonesia. The implementation of this new curriculum with its scientific approach has to deal with some issues in the field. This study reveals that the main problems come from the teachers themselves. All teachers in this study were rather skeptical about the effectiveness of this new curriculum ( and the scientific approach). They personally do not really believe that this approach will work in the field. This has led to another problem that the classroom implementation was not run as expected. Because of some reasons, such as lack of clarity and complexity of teaching procedures, all teachers admitted that they did not really follow the stages of scientific approach in their classroom.

It is important for the government to have a quality control system for this curriculum implementation. The quality control should start through providing more and continuous training and supports for the teachers to understand and implement the curriculum in the field. Last but not least, the government should also open a door of flexibility for the teachers in the implementation of the C13. The government, for instance, should accept different approaches to English teaching. This is because at the end of the day what is more important is not about what is the name of teaching approach a teacher uses; rather whether the approach or strategy works in their English class.

\section{Reference}

[1] Glathorn et all. Curriculum Leadership: Strategies for Development and Implementation. USA: Sage Publication. 2012

[2] Thornton, JS. The Curriculum Studies Reader. New York: Taylor and Francis. 2004

[3] Mulyasa, H.E. Pengembangan dan Implementasi Kurikulum 2013. Bandung: Remaja Rosdakarya. 2013

[4] Azizah, Siti.. Implementasi Pendekatan Saintifik Dalam Pengajaran Bahasa Inggris Kurikulum 2013 di SMPN 1 Pamekasan. OKARA 2 (X): 181-200. 2015

[5] Kemendikbud. Materi Pelatihan Guru Implementasi Kurikulum 2013 SMP/MTs. Jakarta: Kementrian Pendidikan \& Kebudayaan. 2013

[6] Lincoln, Y. S., \& Guba, E. G. Naturalistic inquiry. California: Sage Publications, 1985

[7] Flick, U. An introduction to qualitative research. London: Sage Publication. 2002

[8] Arfianto. From Curriculum Revision to LPTK Regulation. http://www.afriantodaud.com/2015/01/fromcurriculum-revision-to-lptk.html, 2014.

[9] Zaim, M. "Implementing Scientific Approach to Teach English at Senior High School in Indonesia." Asian Social Science. Vol. 13, No. 2. 2017

[11] Kartikawati et al. The Implementation of Saintifik Approach In Teaching English At The Eight Grade Of Smp Muhammadiyah 10 Surakarta: In 2014/ 2015 Academic Year A Naturalistic Study. Skripsi S1. Surakarta: Universitas Muhammadiyah Surakarta. 2015

[12] Nur. MR \& Madkur. A. "Teachers' Voices On The 2013 Curriculum For English Instructional Activities". IJEE, Vol. 1, No. 2. 2014

[13] Arfianti, $A D$. The Implementation of Saintifik Approach in the Teaching of English at SMPN 5 Malang. Skripsi S1. Malang: Universitas Negeri Malang.2014.

[14] Musthafa, B. "Communicative Language Teaching in Indonesia: issues of theoretical assumptions and challenges in the classroom practice." Journal of South Eas Asian Education2(2). 2001

[15] Wahyu GS, Cahyaning. The Implementation of Teaching English Based on 2013 Curriculum to the Seventh Grade Students of SMP N 5 Kediri in Academic Year 2014/2015. Skripsi. Kediri: Universitas Nusantara PGRI Kediri. 2015 